\title{
Nigerian Creole as language of instruction: Will Nigerian lecturers use Nigerian Creole?
}

\begin{tabular}{|c|}
\hline $\begin{array}{l}\text { Author: } \\
\text { Uju C. Ukwuoma }\end{array}$ \\
\hline $\begin{array}{l}\text { Affiliation: } \\
\text { 'Paris \& Drina Consultancy, } \\
\text { Houston, United States of } \\
\text { America }\end{array}$ \\
\hline $\begin{array}{l}\text { Correspondence to: } \\
\text { Uju Ukwuoma }\end{array}$ \\
\hline $\begin{array}{l}\text { Email: } \\
\text { ujucukwuoma@aol.com }\end{array}$ \\
\hline $\begin{array}{l}\text { Postal address: } \\
\text { Paris \& Drina Educational } \\
\text { Consultancy, Post Office Bor } \\
820256 \text {, Houston } 77282, \\
\text { United States of America }\end{array}$ \\
\hline $\begin{array}{l}\text { Dates: } \\
\text { Received: } 26 \text { Jan. } 2015 \\
\text { Accepted: } 16 \text { June } 2015 \\
\text { Published: } 09 \text { Dec. } 2015\end{array}$ \\
\hline $\begin{array}{l}\text { How to cite this article: } \\
\text { Ukwuoma, U.C., 2015, } \\
\text { 'Nigerian Creole as Languag } \\
\text { of Instruction: Will Nigerian } \\
\text { lecturers use Nigerian } \\
\text { Creole?', Reading \& Writing } \\
6(1), \text { Art. \#75, } 8 \text { pages. } \\
\text { http://dx.doi.org/10.4102/ } \\
\text { rw.v6i1.75 }\end{array}$ \\
\hline $\begin{array}{l}\text { Copyright: } \\
\text { (c) 2015. The Authors. } \\
\text { Licensee: AOSIS } \\
\text { OpenJournals. This work is } \\
\text { licensed under the Creative } \\
\text { Commons Attribution } \\
\text { License. }\end{array}$ \\
\hline
\end{tabular}

\section{Read online:}

Scan this QR code with your smart phone or mobile device mobile device
to read online.
This mixed questionnaire survey sought to determine if lecturers who learned to speak and understand Nigerian Creole before English are willing to use the language as medium of instruction. The respondents were comprised of 560 lecturers and graduate students (i.e. master's, doctoral) selected through a purposeful random sampling frame from 15 public institutions of higher learning in Nigeria. Lecturers declined to use Nigerian Creole as medium of instruction because they feared that its use might negatively affect their students' learning of English. Graduate students indicated willingness to receive instruction through a combination of English and Nigerian Creole because they perceived the use of Nigerian Creole as fun and representative of the voice of a new generation of Nigerians. The sample reported that prior knowledge of Nigerian Creole does not facilitate the learning of English because both languages are too different to facilitate a transfer of learning.

\section{Background}

Language of instruction is an indispensable part of teaching and learning. Spoken and written language influences thought patterns and helps teachers and learners vocalise their ideas and assume any role of their choice during instruction (Cazden 2001; Freire \& Macedo 1987; Gee 2011; Vygotsky 1978). Conversely, students in classrooms in multilingual societies represent a divergence of languages, which creates room for competition (Hoffman, Sailors, Makalela \& Matthee 2009). As a result, some teachers align with policy makers and use standard languages over other languages that represent students' experiences (Freire 1978). Be that as it may, the best teachers are those who envision themselves as engineers of the learning environment and employ any language that promotes student learning (Bain 2004). In Nigeria, English is the language of instruction at all levels of education in spite of the 527 languages spoken in the country because fluency in English is erroneously perceived as a hallmark of being educated (Adegbija 2004; Fakeye \& Ogunsiji 2009; Igboanusi 2008; Lewis 2009). Also prevalent is Nigerian Creole, the Sapele and Warri variant of what is often called Nigerian Pidgin language (Ukwuoma 2013), described as the most extensively used pidgin in the world (Faraclas 1996). As such, effort is made to replace Nigerian Pidgin, Naija or Nigerian Pidgin English with Nigerian Creole in previous studies cited in this article

In fact, Nigerian Creole is spoken by 'over 75 million people as a second language and [the] number of first language speakers [is] put roughly at between 3 and 5 million' (Ihemere 2006:297). Yet it does not have any official recognition as a Nigerian language, and lecturers at institutions of higher learning are not using it as a medium of instruction. Consequently, scholars have advocated for official recognition of the language and its use in the Nigerian education system as a subject for students to learn or a language of classroom instruction (Awonusi 1990; Dada 2007; Deuber 2005; Elugbe \& Omamor 1991; Gani-Ikilama 1990; Igboanusi \& Peter 2005; Ndolo 1989; Oladejo 1991; Oloruntoba 1992). Such advocacy is particularly important because findings from several studies have confirmed that 'creole languages can be used as an integral tool for improving educational achievement' (Migge, Leglise \& Bartens 2010:16). However, no study has determined if Nigerian lecturers who learned to speak and understand Nigerian Creole before English are willing to use the language as medium of instruction, or explored the beliefs of such lecturers regarding the instructional utility of Nigerian Creole in formal classroom settings.

Thus, it is important to understand their beliefs because teacher-beliefs birth teacher philosophy which largely determine teacher instructional attitude (Lin 2013; Sercu, Méndez García, \& Castro Prieto 2005). Therefore, the purpose of this study was to determine if lecturers who learned to speak and understand Nigerian Creole before English are willing to use the language as medium of instruction. Three research questions guided the study: 
1. Will lecturers who learned to speak and understand Nigerian Creole before English indicate willingness to teach using Nigerian Creole along with English language?

2. Are graduate students interested in receiving instruction in their content areas through a combination of the English language and Nigerian Creole?

3. Do lecturers and graduate students report that prior knowledge of Nigerian Creole facilitates the learning of English?

\section{Theoretical framework}

The theoretical framework of this study links theories regarding second language acquisition to those within the realm of critical literacy. According to Freire and Macedo (1987), language represents the realities of individuals and should constitute the foundation upon which learning is built. Consequently, a teacher who ignores a learner's own language in preference for a standard language is silencing the most powerful voice a learner has to make sense of what is being taught. Other researchers have emphasised the importance of using a more familiar language as a startingpoint for learning, so that an emotional connection to the subject matter can be created before moving to languages originating from unfamiliar social contexts (e.g. Au 1997; Carrington 2001; Cummins 2009; Migge et al. 2010; Omamor 1983; Siegel 2002). By drawing from prior knowledge of their first language, learners may more easily come to understand new languages. Critical literacy also opens avenues for discussion on existing conditions with regard to permitting language choice. This notion is particularly relevant, because English should not be the sole language for making meaning when an individual's first language is not English.

\section{Review of literature}

Nigeria is a product of the 1914 unsolicited amalgamation of the northern and southern protectorates by Fredrick Lugard under the direction of the Queen of England (Ukwuoma 2013). The country has an estimated population of about 170 million, and languages that are quoted to range between 400 and 527 representing about $20 \%$ of all languages spoken in Africa (Adegbija 1997; Lewis 2009; Simpson \& Oyetade 2008; Central Intelligence Agency 2011). Portuguese was the earliest European language to be used in Nigeria, but at the attainment of political independence in 1960 from Britain, Nigerian officials continued with the English language. French and three other Nigerian languages, namely Hausa, Igbo and Yoruba were later added as co-official languages of the country (Igboanusi 2008; Omoniyi 2003).

Nevertheless, English has remained the language of instruction at all levels of education in the country. The narrow colonial definition of literacy as the ability to read, write and understand English language is also perceived as the goal of education in Nigeria. Thus, students make every possible effort to grapple with English language amidst competing local languages (Crowther, 1962; Ekpe, 2005; Spencer, 1971). Nigeria has a mother-tongue language of instruction policy, which stipulates that every child should be taught in a mother-tongue medium or language of the immediate environment at pre-primary level and during the first three years of primary school (Igboanusi 2008; Oluwole, 2008). Although not officially a Nigerian language, Nigerian Creole qualifies as language of immediate environment in the country as it is spoken by a majority of Nigerians.

Pidgin and creole languages are increasingly used around the world in the media, public health awareness, vocational training and political campaigns because they are capable of facilitating the expression of thoughts as in languages such as Arabic, Chinese, English, French, Russian and Spanish (Bloomfield 1933; Holm 2000; Jespersen 1922; Migge \& Leglise 2007). However, pidgin and creole languages are largely rejected as methods of formal classroom instruction for children who speak them as first languages. This view may be considered to be a human rights violation of such children (Hamel 1995; Skutnabb-Kangas, Phillipson \& Rannut 1994; UNESCO 1968). Several research findings indicate that initial literacy in pidgin and creole languages has a positive effect on future learning, hence the recommendation that learning should begin with languages learners are familiar with instead of alien languages that are from different social contexts (Au 1993; Carrington 2001; Cummins 2009; Migge et al. 2010; Siegel 2002).

Consequently, educators can spur change towards pidgin and creole languages if they accommodate them in formal classroom instruction as a way of engaging in culturally responsive teaching that allows learners to make language choices (Au 1993; Erickson 1987; Hornberger 1998; Kephart 1999; Siegel 1992). In a landmark work that featured how pidgin and creole languages were being used in education, Migge, Leglise and Bartens (2010) gave a description of programmes at the global level to integrate pidgin languages in education. The researchers highlighted three such programmes: accommodation, instrumental, and awarenessraising programmes. Although the researchers did not deal specifically with Nigerian Creole, they found evidence to support the contention that pidgin and creole languages are capable of facilitating teaching and learning. As noted by the authors, there are various ongoing pidgin and creole language programmes in educational institutions in pidginspeaking communities such as Bislama in Vanuatu and Papiamento in Curacao Bonaire among others. Thus, it may be of educational importance to expect a similar development in Nigeria, a country that has pidgin and creole languages existing alongside over 500 languages (Lewis 2009; Online Nigeria n.d.; Simpson \& Oyetade 2008).

\section{Method}

\section{Research design and instrument}

This study was a descriptive research that applied a purposeful random sampling frame (Kemper, Stringfield \& Teddlie 2003). The survey was conducted utilising a researcher-developed mixed questionnaire entitled Nigerian 
Pidgin as Language of Instruction Questionnaire (NPLI-Q), attached as Appendix A. The NPLI-Q was hand-delivered to allow respondents to indicate their preferences on closed questions and to respond to open-ended questions (Bryman 2006). Prior to this study, the NPLI-Q was piloted twice with faculty members and graduate students at a regionally accredited university in southern United States.

\section{Participants and setting}

A total of 560 lecturers and graduate students that comprised of $98.75 \%$ Nigerians $(n=553)$ and $1.25 \%(n=7)$ non-Nigerians from 15 public institutions of higher learning participated in the survey. The institutions included one college of education, one polytechnic, 13 universities located in Abuja, Nigeria's capital city, and pidgin-speaking communities in southern Nigeria. Lecturers made up $38.57 \%(n=216)$ of the survey, whereas graduate students made up $61.25 \%$ $(n=343)$. The respondents, who were speakers of 61 Nigerian languages, resided in 48 cities from various Nigerian ethnic nationalities as indicated in Table 1 . With $48.75 \%$ females $(n=273)$ and $51.25 \%$ males $(n=287)$, the respondents qualified as 'information-rich sources' capable of providing answers to the research questions (Patton 1987:58). Additionally, the respondents had an identical sample relationship because they completed one questionnaire that contained quantitative and qualitative questions (Onwuegbuzie \& Collins 2007). However, respondents who indicated an ethnolinguistic affiliation to Igbo, a Nigerian ethnic group whose first language is also known as Igbo, appeared to have been over-sampled because they featured in all of the surveyed 15 schools. As such, their numerical strength constituted an uncontrollable limitation to this study.

\section{Analysis}

Simple frequency count and percentile distribution were used to analyse structured survey responses to NPLI-Q, whereas responses to open-ended items were coded and categorised using the framework proposed by Bogdan and Biklen (2007). Data from qualitative and quantitative components of NPLI-Q were compared and contrasted to check how they complemented each other in addressing the purpose of the study.

TABLE 1: Ethnic Composition of respondents.

\begin{tabular}{lccc}
\hline Ethnicity & $\mathbf{f}$ & $\mathbf{\%}$ & Cumulative \\
\hline Hausa-Fulani & 18 & 3.21 & 3.21 \\
Igbo & 217 & 38.75 & 41.96 \\
Yoruba & 134 & 23.93 & 65.89 \\
Northern minority & 4 & 0.71 & 66.61 \\
Southern minority & 184 & 32.86 & 99.46 \\
Others & 3 & 0.54 & 100.00 \\
\hline Total & $\mathbf{5 6 0}$ & $\mathbf{1 0 0}$ & - \\
\hline
\end{tabular}

$f$, frequency

TABLE 2a: Order of language learning of lecturers.

\begin{tabular}{lcc}
\hline Order & Result & Total \\
\hline English before NC (\%) & 75.93 & 164 \\
NC before English (\%) & 24.07 & 52 \\
\hline
\end{tabular}

$\mathrm{NC}$, Nigerian Creole

\section{Results}

Tables $2 \mathrm{a}-2 \mathrm{~b}$ display results that answer the first research question from the quantitative component of NPLI-Q. The second and third research questions are addressed in Tables $3,4 \mathrm{a}$ and $4 \mathrm{~b}$ respectively. Both quantitative and qualitative data indicate that most lecturers who learned to speak and understand Nigerian Creole before English did not indicate a willingness to use Nigerian Creole as a medium of instruction. Their reasons ranged from a lack of a generally accepted orthography for Nigerian Creole to personal fears regarding how its use might negatively affect students' learning of English. They also cited their concerns over the limited technical vocabulary of Nigerian Creole. Graduate students indicated their preference in receiving instruction through a combination of Nigerian Creole and English language. Graduate students did so because they see the use of Nigerian Creole as fun. They also believe that its use allows wider communication in Nigeria. Graduate students are convinced that Nigerian Creole represents their voice, the voice of a new generation of Nigerians. Some graduate students blame the abuse of power by policy makers on the non-use of Nigerian Creole as a medium of instruction. Half of the graduate students, and most lecturers, did not believe that prior knowledge of Nigerian Creole facilitates the learning of English. Both graduate students and lecturers regard the two languages as being too different to facilitate transfer of learning. Some expressed fear that knowledge of Nigerian Creole may negatively influence the learning of English because of certain grammatical similarities shared by both languages.

\section{Discussion}

\section{Orthography of Nigerian Creole}

The purpose of this study was to determine if lecturers who learned to speak and understand Nigerian Creole before

TABLE 2b: Willingness of Lecturers who Learned NC before English to Teach Using NC.

\begin{tabular}{lc}
\hline Willingness & Amount \\
\hline Will use & 10 \\
Will not use & 42 \\
\hline NC, Nigerian Creole &
\end{tabular}

TABLE 3: Will Graduate Students Receive Instruction Using NC?

\begin{tabular}{lcc}
\hline Willingness & Result & Total \\
\hline Will receive (\%) & 50.15 & 167 \\
Will not (\%) & 49.25 & 764 \\
\hline
\end{tabular}

$\mathrm{NC}$, Nigerian Creole

TABLE 4a: Does Knowledge of NC Facilitate the Learning of English?

\begin{tabular}{lccccc}
\hline Variable & $\begin{array}{c}\text { Strongly } \\
\text { disagreed }\end{array}$ & Disagreed & Agreed & $\begin{array}{c}\text { Strongly } \\
\text { agreed }\end{array}$ & Neutral \\
\hline Lecturers & 37.50 & 26.39 & 11.11 & 8.80 & 16.20 \\
$n$ & 80 & 57 & 24 & 19 & 35 \\
\hline
\end{tabular}

TABLE 4b: Does knowledge of NC facilitate the learning of English?

\begin{tabular}{lccccc}
\hline Variable & $\begin{array}{c}\text { Strongly } \\
\text { disagreed }\end{array}$ & Disagreed & Agreed & $\begin{array}{c}\text { Strongly } \\
\text { agreed }\end{array}$ & Neutral \\
\hline $\begin{array}{l}\text { Graduate } \\
\text { students }\end{array}$ & 25.66 & 26.53 & 14.87 & 7.00 & 25.95 \\
$n$ & 88 & 91 & 51 & 24 & 89 \\
\hline
\end{tabular}


English are willing to use Nigerian Creole as a medium of instruction. Admittedly, Nigerian Creole is a tonal language that has given linguists many problems with representation in writing (Elugbe \& Omamor 1991; Mafeni 1971; Oyebade 1983). However, linguists such as Elugbe and Omamor (1991) and Faraclas (1996) have developed phonemic orthographies for the language. In 2009, the Naijá Langwej Akedemi, a committee for harmonising Nigerian Pidgin Language, proposed a harmonised orthography for writing the language (Esizimetor \& Egbokhare n.d.). Sowunmi and Hankey (2003) is a primer on Nigerian Pidgin. In addition, Okonkwo et al.'s (2007) Mek Wi Rid Naijiria Pijin is another primer for teaching how to read and write the language. Interestingly, Naijiria Pijin Lanwej Baibul (2011) published by Mercy Christian Ministry International is a translation of the Bible into the variants now known as Nigerian Creole. Considering the degree of orthographic consistency maintained in some of the above works, the issue of a lack of orthography appears to have been addressed.

\section{Nigerian Creole and English language learning}

Although this study did not set out to measure the effect of Nigerian Creole on the learning of English, a lecturer within the age bracket of 55-60, who had taught for over 23 years in one of the surveyed schools in southern Nigeria, indicated that 'Nigerian Creole will negatively affect my students' efforts to learn English language'. However, available literature on Nigerian Creole does not portray the language in such light. Aina (1991), who administered a standard English test of oral reading, essay composition, and silent reading comprehension to 10 students in a public secondary school in southern Nigeria, found that knowledge of Nigerian Creole enhances reading comprehension of English. However, she discovered that the language inhibits the writing of English because the sampled students were prone to errors such as mistaking meet for meat, a problem the researcher inferred can be solved by developing the morphology of Nigerian Creole. To teach Nigerian Creole, Igboanusi (2008:6) suggested that teachers should point out the 'differences and similarities between the language and English'. Igboanusi is of the opinion that teaching Nigerian Creole as a subject in schools the way English is being taught will enable users of both languages to understand inherent differences. Nevertheless, the congruence in opinion of graduate students and lecturers that English and Nigerian Creole are different from each other is consistent with research findings that Nigerian Creole is not English or a dialect of English (Akande 2010; Ihemere 2006). On the grammar of Nigerian Creole, Mensah (2012:167) has shown that it is 'not contact induced from English but rather a language - internal phenomenon'. The problem of absence or limited technical vocabulary in Nigerian Creole can be tackled through status planning, which should begin with the Nigerian government duly recognising Nigerian Creole as a Nigerian language (Igboanusi 2008). Faraclas (1996) described Nigerian Creole as the most widely spoken language in Nigeria. Other scholars have identified the language as being systematic and rule governed, thus capable of fulfilling human linguistic needs as one would expect from languages such as Arabic, Chinese, English, French, Russian and Spanish (Bloomfield 1933; Holm 2000; Ihemere 2006; Jespersen 1922; Migge \& Leglise 2007).

\section{Nigerian Creole and emotional connection in familiar language}

In her remarks, a female graduate student asked: 'Can you imagine how awesome it will be to teach my students mathematics in Nigerian Creole when I graduate? It will truly be fun'. Research findings have consistently shown that students stand a better chance of meeting instructional objectives when teachers begin with familiar languages ( $\mathrm{Au}$ 1997; Cummins 2009). One must concede that 'knowledge is constructed based on social interactions and experience' (Woolfolk 1999:279), and Nigerian Creole is the preferred language of social interaction amongst Nigerian youths in institutions of higher learning (Ajibade, Adeyemi \& Awopetu, 2012). It follows that Nigerian Creole should not be seen as less suitable for a medium of instruction. Furthermore, lecturers should consider the fact that Nigerian Creole is the language their students use to make sense of their experiences and generate new knowledge (Freire \& Macedo 1987). Such a language that forms part of students' everyday social contexts may facilitate learning if it is included in school instruction. Similarly, graduate students consider Nigerian Creole as belonging to a new generation of Nigerians who have understood the linguistic and ethnic diversity of Nigeria. They now prefer Nigerian Creole because it is neutral and enjoys cross ethnic acceptance in Nigeria. A graduate student pointed out that 'Nigerian Creole is our own, it does not represent any ethnic group in Nigeria but policy makers will not allow us use the language in school because it will unite us, I think it has to do with power and corruption'.

\section{Conclusion}

The literacy rate of Nigeria is put at $61.3 \%$ (CIA 2011). Perhaps literacy is still being measured for Africa's most populous country as the ability to read and write the English language (Adetugbo 1984; Awonusi 2004; Bamgbose 1995; Ekpe 2005). Such perception calls for repositioning another Nigerian language alongside English. The performance of Nigerian students in English contrasts with popular perceptions in Nigeria regarding the dominant role of English (AduwaOgiegbaen 2006; Akeredolu-Ale 2007; Omo-Ojugo 2004), hence the need to incorporate Nigerian students' first language in instructional practices. This study reveals that university lecturers, who might themselves be able to employ Nigerian Creole as a medium of instruction, have negative attitudes towards the language because of societal prejudice or fear that students will not learn English.

At the same time, the younger generation is more open to its use because they feel it better represents their voice. Clearly, there is misunderstanding and prejudice surrounding Nigerian Creole since it is often seen amongst the Nigerian people as merely an ungrammatical form of English, 
spoken by those who they deem less educated. In fact, most pidgin varieties in Nigeria have become creolised. Policy shift is needed to educate the populace about the value of vernacular languages. There is a role for universities and, more specifically, teacher education programmes for such an educational campaign.

Future research on incorporating Nigerian Creole into formal education as a medium of instruction should take several steps. First and foremost, this study should be replicated in secondary schools and other institutions of higher learning in southern Nigeria, particularly in colleges of education. Secondly, research should use poor performance in English and fluency in Nigerian Creole as outcome variables to determine the effect of the use of Nigerian Creole on students' performance in English and language arts. Such studies may provide the necessary empirical base that can prompt an evidence-based assertion on whether Nigerian Creole can be a standalone language of instruction or be used along with English as a medium of instruction. Nevertheless, in answer to the question posed in the title of this work, statistical evidence from this study suggests that Nigerian lecturers may not use Nigerian Creole as a language of instruction.

\section{Acknowledgements Competing interests}

The author declares that he has no financial or personal relationships which may have inappropriately influenced him in writing this article.

\section{References}

Adegbija, E., 1997, 'The language factor in achievement of better results in literacy programs in Nigeria: Some general considerations', in B. Smeija \& M. Tasch (eds.), Human contact through language and linguistics, pp. 221-242, Peter Lang, Berlin, Germany.

Adegbija, E., 2004, Multilingualism: A Nigerian case study, Africa World, Lawrenceville.

Adetugbo, A., 1984, The English language in the Nigerian experience: An inaugura lecture delivered at the University of Lagos on Friday, 21st march, 1980, University of Lagos, Lagos.

Aduwa-Ogiegbaen, S.E., 2006, Factors that affect quality of English teaching and learning in secondary schools in Nigeria, CBS Interactive Business Network, viewed n.d., from http://findarticles.com/p/articles/mi_m0FCR/is_3_40/ai_n16726393/

Aina, J.O., 1991, 'Action research on effects of a Pidgin English', Journal of Reading 35, 242-243.

Ajibade, Y.A., Adeyemi, A.A., \& Awopetu, E.O., 2012, 'Unity in diversity: The Nigerian youth, Nigerian Pidgin English and the Nigerian language policy', Journal of Educational and Social Research 2, 289-295.

Akande, A., 2010, 'Is Nigerian Pidgin English English?', Dialectologia et Geolinguistica 18, 3-22. http://dx.doi.org/10.1515/dig.2010.001

Akeredolu-Ale, B., 2007, 'Good English for what: Learners' motivation as a factor in declining learners' performance in English language acquisition and use in Nigerian schools', Changing English 15, 231-245. http://dx.doi. org/10.1080/13586840701443065

Au, K.H., 1993, Literacy instruction in multicultural settings, Holt, Rinehart and Wilson, Florida.

$\mathrm{Au}$, K.H., 1997, 'A sociocultural model of reading instruction: The Kamehameha elementary education program', in S. Stahl \& D. Hayes (eds.), Instructional models in reading, pp. 181-202, Erlbaum, Hillsdale.

Awonusi, V.O., 1990, 'Planning for a national (Nigerian) language', in A.E. Eruvbetine (ed.), Aesthetics and utilitarianism in languages and literatures, Lagos State University, Lagos.

Awonusi, V.O, 2004, 'Cycles of linguistic history: The development of English in Nigeria', in A.B.K. Dadzie \& V.O Awonusi (eds.), Nigerian English: Influence and characteristic, Concept, Lagos, Nigeria.

Bain, K., 2004, What the best college teachers do, Harvard University Press, Cambridge.

Bamgbose, A., 1995, 'English in the Nigerian environment', in A. Bamgbose, A. Banjo \& A. Andrews (eds.), New Englishes: A West African perspective, Mosuro, Ibadan.
Bloomfield, L., 1933, Language, Henry Holt, New York.

Bogdan, R. \& Biklen, S., 2007, Qualitative research for education, 5th edn., Allyn \& Bacon, Boston.

Bryman, A., 2006, 'Integrating quantitative and qualitative research: How is it done?', Qualitative Research 6(1), 97-113. http://dx.doi.org/10.1177/1468794106058877

Carrington, L., 2001, 'The status of Creole in the Caribbean: In due respect', in P. Christie (ed.), Papers on English and English-related Creoles in the Caribbean in honour of Professor Robert LePage, pp. 24-36, University of the West Indies, Trinidad \& Tobago

Cazden, C.B., 2001, Classroom discourse: The language of teaching and learning, Heinemann, Portsmouth.

Central Intelligence Agency, 2011, CIA world fact book: Nigeria, viewed n.d., from https://www.cia.gov/library/publications/the-world-factbook/geos/ni.html.

Crowther, M., 1962, The story of Nigeria, Faber Publication, London.

Cummins, J., 2009, 'Fundamental psycholinguistic and sociological principles underlying educational success for linguistic minority students' in T. SkutnabbKangas, R. Phillipson, A. Mohanty \& M. Panda (eds.), Social justice through multilingual education, Multilingual Matters, Bristol.

Dada, S.A., 2007, 'Language contact and language conflict: The case of Yoruba-English bilinguals', Kansas Working Papers in Linguistics 29, 85-113.

Deuber, D., 2005, Nigerian Pidgin in Lagos, Battlebridge, London.

Ekpe, M.B., 2005, 'Glocalization of English lexis in Nigeria', Calabar Journal of Liberal Studies (CAJOLIS) IX, 29-40.

Elugbe, B.O. \& Omamor, A.P., 1991, Nigerian Pidgin: Background and Prospects, Heinemann, Ibadan.

Erickson, B., 1987, 'Pidgin draws flak, support, call for Hawaiian', The Honolulu Advertiser, 02 September, p. A19.

Esizimetor, D. \& Egbokhare, F., n.d., Language varieties: Naijá (Nigerian Pidgin), viewed n.d., from http://www.hawaii.edu/satocenter/langnet/definitions/naija. html

Fakeye, D.O. \& Ogunsiji, Y., 2009, 'English language proficiency as a predictor of academic achievement among EFL students in Nigeria', European Journal of academic achievement among
Scientific Research 37, 490-495.

Faraclas, N.G., 1996, Nigerian Pidgin, Routledge, New York. http://dx.doi. org/10.4324/9780203192801

Freire, P., 1978, Pedagogy in process, Seabury, New York.

Freire, P. \& Macedo, D., 1987, Literacy: Reading the word and the world, Bergin \& Garvey, South Hadley.

Gani-Ikilama, T.O., 1990, 'Nigerian Pidgin in education? Why not?', in E. Emenanjo (ed.), Multilingualism: Minority languages and language policy in Nigeria, pp. 219-227, Central Books, Agbor.

Gee, J.P., 2011, An introduction to discourse analysis: Theory and method, Routledge, New York.

Hamel, R.E., 1995, Derechos humanos linguisticos en sociedades multiculturales, 5th edn., vol. 10, Universidad Autonoma Metropolitana, Mexico City, Mexico.

Hoffman, J.V., Sailors, M., Makalela, L. \& Matthee, B., 2009, 'Language policy and literacy instruction', in J. Hoffman \& Y. Goodman (eds.), Changing literacies for changing times, Taylor \& Francis, New York.

Holm, J., 2000, An introduction to pidgins and creoles, Cambridge University, Cambridge. http://dx.doi.org/10.1017/CBO9781139164153

Hornberger, N.H., 1998, 'Language policy, language education, language rights: Indigenous, immigrant and international perspectives', Language in Society $27(4)$ 439-458. http://dx.doi.org/10.1017/S0047404500020182

Igboanusi, H., 2008, 'Empowering Nigerian Pidgin: A challenge for status planning?', World Englishes 27, 68-82. http://dx.doi.org/10.1111/j.1467-971X.2008.00536.x

Igboanusi, H. \& Peter, L., 2005, Languages in competition, pp. 27-35, Peter Lang, Frankfurt, Germany.

Ihemere, K.U., 2006, 'A basic description and analytic treatment of noun clauses in Nigerian Pidgin, Nordic Journal of African Studies 15, 296-313.

Jespersen, O., 1922, Language: Its nature development and origin, Allen \& Unwin, London, viewed n.d., from http://ia700508.us.archive.org/22/items/ languageitsnatur00jespiala/languageitsnatur00jespiala.pdf

Kemper, E., Stringfield, S. \& Teddlie, C., 2003, 'Mixed methods sampling strategies in social science research', in A. Tashakkori \& C. Teddlie (eds.), Handbook of mixed methods in social science \& behavioural research, pp. 273-296, Sage, Thousand Oaks.

Kephart, R., 1999, 'Report on a creole English experiment', paper presented at the seminar on language, education and culture in the context of the western Caribbean, San Andres, Columbia.

Lewis, M. Paul (ed.), 2009, Ethnologue: Languages of the World, 16th edn., SIL International, Dallas, TX, viewed n.d., from http://www.ethnologue.com/

Lin, Z., 2013, 'Language teachers' attitudes, beliefs, professional knowledge, and views on professional development: An exploratory study at a preschool TEFL setting', TESOL Journal 4(1).

Mafeni, B., 1971, 'Nigerian Pidgin', in J. Spencer (ed.), The English language in West Africa, pp. 95-112, Longman, London.

Mensah, E.O., 2012, 'Grammaticalization in Nigerian Pidgin', Ikala Revista de Lenguaje y Cultura 17, 167-179.

Mercy Christian Ministry International, 2011, Naijiria pijin lanwej baibul, Mercy Christian Ministry International, Florida. 
Migge, B. \& Leglise, I., 2007, 'Language and colonialism', in M. Hellinger \& A. Pauwels (eds.), Handbook of language and communication: Diversity and change, Mouton de Gruyter, Berlin. http://dx.doi.org/10.1075/cll.36.01mig

Migge, B., Leglise, I. \& Bartens, A., 2010, 'Creoles in education: A discussion of pertinent issues', in B. Migge, I. Leglise \& A. Bartens (eds.), Creoles in education An appraisal of current programs and projects, vol. 36, pp. 1-30, John Benjamins, Amsterdam.

Ndolo, I.S., 1989, 'The case of promoting Nigerian Pidgin language', Journal of Modern African Studies 27, 679-684.

Okonkwo, R.C., Chikwere, F.N., Godwins-Divine, H., Okoro, O., Udoh, C., Enaboakpe, K.O., Gilbert, G.I. \& Okoro, C.O., 2007, Mek wi rid naijiria pijin, Literacy International, Owerri, Nigeria.

Oladejo, J., 1991, 'The national language question in Nigeria: Is there an answer?', Language Problems and Language Planning 15, 256-267. http://dx.doi. org/10.1075/Iplp.15.3.01ola

Oloruntoba, C.I., 1992, 'Sociocultural dimensions of Nigerian Pidgin usage (West Niger Delta of Nigeria)', PhD thesis, available from ProQuest. (UMI 9231615).

Oluwole, D.A., 2008, 'The impact of mother tongue on students' achievement in English language in junior secondary examination in western Nigeria', Journal of Social Sciences 17(1), 41-49.

Omamor, A. P., 1983, 'Towards extricating Nigerian Pidgin (NP) from a straight jacket: A preliminary study', paper presented at the 14th annual conference on African linguistics, Wisconsin.

Omoniyi, T., 2003, 'Language ideology and politics: A critical appraisal of French as second official language in Nigeria', AILA Review 16, 13-25. http://dx.doi. org/10.1075/aila.16.03omo

Omo-Ojugo, O.M., 2004, November. 'Esan language endangered? Implications for the teaching and learning of indigenous languages in Nigeria', lecture presented at the Ambrose Alli University's inaugural lecture series, Ekpoma, Nigeria, November, 2004.

Online Nigeria. n.d., Nigerian languages, viewed from http://www.onlinenigeria.com/ languages/languages.asp

Onwuegbuzie, A.J. \& Collins, K.M.T., 2007, 'A typology of mixed methods sampling designs in social science research', The Qualitative Report 12, 281-316.
Oyebade, F.O., 1983, 'Aspects of the phonology of Nigerian Pidgin English. Project for the M.A. (linguistics) degree University of Ibadan', Master's thesis, University of Ibadan.

Patton, M.Q., 1987, Creative evaluation, 2nd edn., Sage, Newbury Park.

Sercu, L., Méndez García, M.C. \& Castro Prieto, P., 2005, 'Scaffolding culture learning: An investigation of teacher approaches', Language and Education 19(6), 483-495. http://dx.doi.org/10.1080/09500780508668699

Siegel, J., 1992, 'Teaching initial literacy in a pidgin language: A preliminary evaluation', in J. Siegel (ed.), Pidgins Creoles and Nonstandard Dialects in Education, pp. 53-62, Applied Linguistics Association of Australia, Melbourne.

Siegel, J., 2002, 'Applied creolistics in the twenty-first century', in G. Gilbert (ed.), Pidgin and creole linguistics in the twenty-first century, pp. 7-48, Peter Lang, New York.

Simpson, A. \& Oyetade, B.A., 2008, 'Nigeria: Ethno-linguistic competition in the giant of Africa', in A. Simpson (ed.), Language and national identity in Africa, pp. 172-198, Oxford University, Oxford.

Skutnabb-Kangas, T., Phillipson, R. \& Rannut, M., 1994, Linguistic human rights: Overcoming linguistic discrimination, Mouton de Gruyter, New York.

Sowunmi, B. \& Hankey, M., 2003, A beg o make una dey blow pidgin: A primer on Nigerian Pidgin, US Department of State, Washington, DC.

Spencer, J., 1971, 'West Africa and the English language', in J. Spencer (ed.), The English Language in West Africa, pp. 1-34, Longman, Leeds.

Ukwuoma, U.C., 2013, 'African urban and youth language as medium of instruction: Case study of Nigerian creole', paper presented at the African Urban and Youth Language Conference in Cape Town, South Africa.

UNESCO, 1968, 'The use of vernacular languages in education: The report of the UNESCO meeting of specialists, 1951', in J. Fishman (ed.), Readings in the sociology of language, pp. 688-716, Mouton, Hague, Netherlands. http://dx.doi. org/10.1515/9783110805376

Vygotsky, L., 1978, Mind in society: The development of higher psychological processes, Harvard University, Cambridge.

Woolfolk, A.E., 1999, Educational psychology, 7th edn., Allyn \& Bacon, Boston. 


\section{Appendixes}

\section{Appendix A}

Nigerian Pidgin as a Language of Instruction Questionnaire (NPLI-Q)

\section{PLEASE CHECK THE CATEGORY THAT APPLIES TO YOU:}

1. Indicate your gender:

() Female

() Male

2. Nationality:

() Nigerian

() Non Nigerian

3. Indicate your ethnic group:

() Hausa-Fulani () Igbo () Yoruba

() Northern minority ethnic groups () Southern minority ethnic groups

( ) Others: (Please specify)

4. What is your native language?

5. What is your age group?
( ) 20 \& under
() $21-25$
() $26-30$
() 31-35
() $36-40$
( ) $41-45$
() $46-50$
( ) 50-55
() 56 \& above

6. What is your current city of residence?

7. How many years have you lived in this city?

8. I am a () lecturer () graduate student

\section{PLEASE RESPOND TO QUESTIONS 8-10 BASED ON YOUR LEVEL OF PROFICIENCY:}

9. My ability to speak and understand English language is:
() Poor
() Fair
() Good
() Very good
( ) Excellent

10. My ability to speak and understand Nigerian Pidgin is:
() Poor
() Fair
() Good
() Very good
( ) Excellent

11. Which of the following languages did you learn to speak and understand before the other?

() English Language () Nigerian Pidgin

\section{PLEASE CIRCLE THE ANSWER THAT BEST FIT YOUR OPINION:}

The rating scale of $1-5$ indicates: $\quad \mathbf{1}=$ Strongly Disagree, $\mathbf{2}=$ Disagree, $\mathbf{3}=$ Neutral,

12. My knowledge of Nigerian Pidgin $\mathbf{4}=$ Agree, $\mathbf{5}$ = Strongly Agree.

helps me to learn and understand English

Language

13. My knowledge of English Language helps me to learn and understand Nigerian Pidgin

$\begin{array}{lllll}1 & 2 & 3 & 4 & 5 \\ 1 & 2 & 3 & 4 & 5\end{array}$

\section{LECTURERS; PLEASE RESPOND TO ITEMS 14-18:}

14. Which language do you currently use while teaching your students in a formal classroom setting?
() English Language only
( ) Nigerian Pidgin only
( ) English Language and Nigerian Pidgin.
() Others (Please specify)

15. Would your course contents be better explained using Nigerian Pidgin?
() No
() Yes

16. Would the use of Nigerian Pidgin as a language of instruction alongside English language facilitate comprehension for your students?
( ) No
() Yes

17. Briefly explain the reason for your answer on item 16 above:

18. How many years of post secondary school teaching experience do you have?

\section{GRADUATE STUDENTS; PLEASE RESPOND TO ITEMS 19-23:}

19. Does your lecturer switch between English language and Nigerian Pidgin while teaching you in a formal classroom setting?
() No
() Yes

20. Besides English language, what other language or languages does your lecturer speak while teaching you in a formal classroom setting? 
21. Would concepts you learn in class be easier to comprehend if the lecturer taught them using Nigerian Pidgin?
( ) No
() Yes

22. Briefly explain the reason for your answer on item 20 above:

23. Should lecturers use Nigerian Pidgin alongside English language to teach?
() No
() Yes

\section{FROM A LECTURER OR GRADUATE STUDENT'S PERSPECTIVE:}

24. Please note anything else you think is important for the researcher to consider:

Thank you for completing this questionnaire! 